\title{
A REVIEW ON RECENT DEVELOPMENTS IN SOLARPHOTOVOLTAIC CELL TECHNOLOGY
}

\section{Rajmati Mahaveer Patil}

Department of ME

SIT COE, Yadrav, Maharashtra, India

Nikita Shital Mane

Department of ME

SIT COE, Yadrav, Maharashtra, India

\author{
Shubham Satish Kulkarni \\ Department of ME
}

SIT COE, Yadrav, Maharashtra, India

\begin{abstract}
This review paper mainly examines the need and scope of the solar photovoltaic cell technology. Every passing year, the global electricity and power consumption ratio is going sky-high. And many technologies have been emerging so as to meet and fulfill this ever growing demand and supply numbers. Solar photovoltaic cell technology is such a renewable kind of technology which has high ability as well as potential to strengthen the luminous electricity system with more reliability and assurance. This paper mainly studies inclusive review of solar photovoltaic technology.
\end{abstract}

KEYWORDS- Photovoltaic Materials, Photovoltaic Efficiency, PV Modules, Nanoparticles, Silver Nanoparticles, Solar Cell, Gold island films.

\section{INTRODUCTION}

\subsection{Basics of solar photovoltaic cell technology-}

Renewable sources of energy are the only sources to achieve the clean energy, as non- renewable sources of energy are depleting and in near future the renewable sources of energy are only one which will help the world to achieve the energy goals. Renewable energy can be obtained from many sources such as tidal, wind, solar, geothermal, hydro and biomass. This paper only focuses on solar energy, how solar cells operates, how solar cell works, what are the applications of solar technology, how the efficiency of solar cells can be increased.[1] Solar technology works on photovoltaic effect in which solar cells absorbs the sun radiations and generate the electricity. As solar radiations falls on the solar cell, it causes the excitement of the electron in the doped region of solar cell, due to this electron-hole
Abhishek Vrushabh Chougule

Department of ME

SIT COE, Yadrav, Maharashtra, India

Komal Sanjay Chakote

Department of ME

SIT COE, Yadrav, Maharashtra, India

Avesahemad S N Husainy

Department of ME

SIT COE, Yadrav, Maharashtra, India pairs are formed and the electric current is generated. The solar technology can also be used for generating the heat later used for different applications. [2] The conversion efficiency of a solar cell is also an important factor that influences the production of electricity from a single solar cell. A lot of research has been done to increase the conversion efficiency. A single solar cell is manufactured from the desired material, then a solar module is made by arranging a number of solar cells and solar array is made by arranging number of solar module. [3]

\subsection{Need of this technology-}

The energy can be produced by both ways i.e. directly and indirectly with the help of some kind of resources. The use of natural resources such as fossil fuels, coals, oil, natural gases leads to great threat to environment and mother nature in sense of using the forest cutting which leads further into deforestation, release of hydrocarbons, paraffin's. The rapidly growth in energy consumption by the generation and the growing demand of energy supply,it is a big major issue and a huge challenge in front of whole world itself.[4] The PV panels are highly promoted for energy production, it does not have any environmental restrictions because it does not emit any harmful gases like carbon dioxide which contributes to increases the global warming rate to meet the global energy in sustainable way.[5] But the fact is Only 30 minutes of solar radiations are enough to create a global energy.[6] Solar energy is collected and utilized by this technology.[7] 


\section{International Journal of Engineering Applied Sciences and Technology, 2021 \\ Vol. 5, Issue 11, ISSN No. 2455-2143, Pages 211-216 \\ Published Online March 2021 in IJEAST (http://www.ijeast.com)}

\subsection{Different materials used for PV cell-}

Silicon is the most commonly used material for solar cell, solar cell is manufactured by arranging the layers of the silicon and then upper and bottom layer of the silicon are doped, i.e. impurities are added[8] like Amorphous Silicon, Polycrystalline or Multi crystalline Silicon, Monocrystalline Silicon, Copper Indiume Galliume Selenium (CIGS), Cadmium Telluride (CdTe), Copper Indiume Selenium (CIS) [9,10]. There are some different types of solar panels used, based on their application i.e. used for generating electricity, heat or both electricity and heat. They are -

1. Photovoltaic cells (PV) - Used for generating electricity from the sunlight.

2. Thermal collectors - Used for generating the heat from sunlight and this heat can be used for heating water or for other application.

Photovoltaic-thermal (known as PV/T) panels - Used for the solar energy to produce both electricity and heat concentrating solar panels - Used for generating excessive amount of heat by focusing the sunlight at one point [11].

1.4 Advantages of solar PV cell technology-

Some advantages of solar energy in India are as follows -

1. Solar energy is environment friendly, when used, it does not released $\mathrm{CO} 2$ and other toxic and hazardous gaseous which pollutes the air.

2. Solar energy can be used for variety of uses like as heating, drying, cooking orelectricity, which is suitable for rural areas in India.

3. It also used in cars, planes, large power boats, satellite and many more such items. It just application for urban population.

4. Solar panels can be easily placed in houses and it is quite inexpensive compared toother sources of energy. [12,13]

\section{EFFICIENCY ENHANCEMENT TECHNIQUES USED FOR SOLAR CELLS-}

\subsection{Using a textured and reflective surface in solar pv cell:}

The efficiency of n-i-p-p+ hydrogenated amorphous silicon cell $(\mathrm{Si}: \mathrm{H})$ can be increased by replacing the substrate by textured and reflective front and back end [14]. The simulation on 2D realistic model based on TCAD Sentarus of different textured surface with different size of periods (p) and heights (h) has been done [15] An intrinsic layer is sandwiched between $p$ doped and $\mathrm{n}$-doped region to generate electricity [14]. To increase the efficiency of this silicon cell it should be made optically wide and electrically narrow. This increases the optical path of the photons and also it promotes absorption of the photons and hence increases the efficiency [16].

Following figures describes the difference between flat
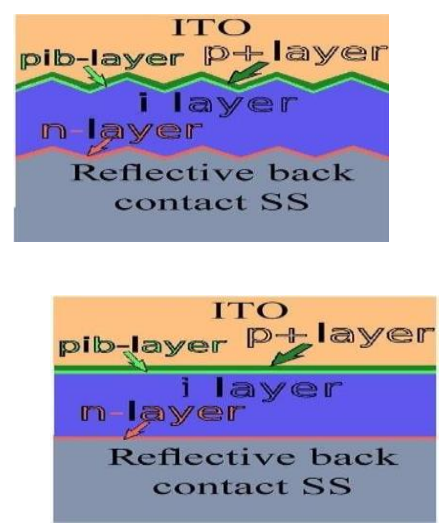

surface and textured surface of Si:H solar cell-

Fig.1- Silicon solar cell with flat surface:

Fig.2- Silicon solar cell with textured surface:

Fig.1 and Fig.2 shows difference between flat surface and textured surface [17]

In fig. 2 the p-doped region and $\mathrm{n}$-doped region are textured in zig-zag manner so that light can be reflected several times and it can be efficiently absorbed by the intrinsic layer. The enhancement of internal scattering and reflection is beneficial for the wavelength of red and infrared range light and the absorption length of Si:H increase by $1 \mu \mathrm{m}$ or also by $10 \mu \mathrm{m}$ [18].

\subsection{Using indium tin oxide as a front end contact in solar cell:}

ITO (Indium Tin Oxide) as a front contact in a solar cell to increase the efficiency of solar cell. In this CIGS solar cell structure consist of base layer of molybdenum, second layer of CIGS, third layer of CdS (Buffer Layer) this is sandwiched between the $\mathrm{ZnO}$ and CIGS. Thennext layer is of $\mathrm{ZnO}$ which is undoped, this costs very less and also it is very stable and non- toxic. The last layer is of ITO which is top layer, this layer is very lightweight, very flexible and it is $120 \mathrm{~nm}$ wide. The structure of CIGS solar cell is shown in figure (3). 


\section{International Journal of Engineering Applied Sciences and Technology, 2021 \\ Vol. 5, Issue 11, ISSN No. 2455-2143, Pages 211-216 \\ Published Online March 2021 in IJEAST (http://www.ijeast.com)}

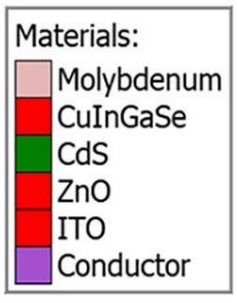

Fig.3 Structure of a CIGS solar cell with ITO front end.

For determining the solar cell with ITO as a front end is more efficient tests taken to compare thefill factor (FF) and efficiency, voltage at maximum power density, maximum output power (Pm), short circuit current density (Jsc), open circuit voltage (Voc) of solar cell with ITO to solar cell without ITO. [19] Following figure shows the results of comparison of above parameters -

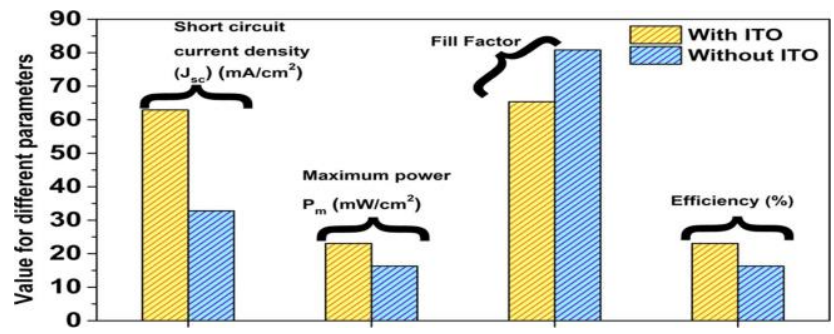

Fig.4 Comparison of parameters of solar cell with ITO and without ITO

From fig.4 it proves that the short circuit current density (Jsc) of an solar cell with ITO is greater than solar cell without ITO. The reason behind this is the ITO absorbs a greater number of photons and generates a large number of charge carriers. The current generated is dependant in number if charge carriers, hence as charge carriers increases the current generation also increases. [20]

\subsection{Using gold nano particle for efficiency improvement of solar cell:}

According to A. Axelevitch et.al, the main reason behind solar cells are not being used globally in wide spread is their high cost and comparatively low in efficiency performance. In the luminescence recombination process of solar cells, optical and electrical losses takes place abundantly and thus is was arduous to get efficiency of solar cell $31 \%$ theoretically[21, 22]. So as to eliminate this lacuna authors used non continuous, thin island gold films which were deposited on a dielectric or semiconductor

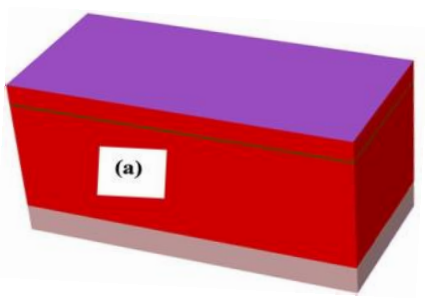

surface which acts unique in nature. As a result, in the response of light exposure up to a certain range, the metal island presents a resonant absorption of light among the collective behavior of free electrons there. This phenomenon can also be described by the appearance of localized plasmons polaritons with intensity and frequency that are relative to the size of the particles. By doing so, efficiency of solar cells can be increased notably by using nano dimensional gold island embedded in semiconductor junctions. Although there are many ways to increase efficiency of photovoltaic solar cells, one of the reliable way is utilizing various semiconductor materials in order to enlarge the spectral efficiency by capturing various parts of solar spectrum where a top cell captures the high energy photons and passes the rest by lowering band gap in cells[23]. Another way to increase the efficiency of photovoltaic solar cells is utilizing higher energy photons than the semiconductor band gap. These photons generate higher energy than the Fermi level. Many researchers have tried to use the SPR to increase the efficiency of photovoltaic solar cell previously. For this, the metallic nanoparticles of metals such as $\mathrm{Au}, \mathrm{Ag}, \mathrm{Cu}$, and $\mathrm{Al}$ were deposited on the surface of solar cells. It was found that the three mechanisms can be used effectively to increase the light trapping in the solar cells [24-28]. To improve the light trapping, various forms and shapes of nano particles were modelled and studied using finite-difference timedomain (FDTD) method. Unfortunately they were not that useful as expected. Nevertheless, many attempts has tried to overcome this. The thin island metal film consists of metal particles with nano-dimensions. It was found that the width and peak position of the SPR depend on the particle size, shape and environment. [29, 30]

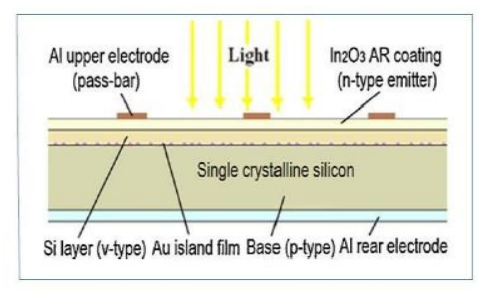

Fig 5 Proposed PV system [31]

Thus, the SPRs can be considered not only as a means for improving the optical absorption in thesemiconductor, but as a source of additional electrons obtained by absorption of "hot" or high- energy photons. As shown, the system comprise of p-type single-crystalline silicon substrate, $\mathrm{Al}$ rear continuous electrode, and a sequence of various thin films on the active (upper) surface of the substrate. Gold and silicon thin films in this system were deposited using a home-made laboratory triode sputtering vacuum station realizing a plane-shape plasma discharge. Anti-reflecting transparent conductive In2O3 coatings (AR) were deposited 


\section{International Journal of Engineering Applied Sciences and Technology, 2021 \\ Vol. 5, Issue 11, ISSN No. 2455-2143, Pages 211-216 \\ Published Online March 2021 in IJEAST (http://www.ijeast.com)}

using a magnetron sputtering method. After the deposition of the AR thin film, the built multi-layer system was thermally treated in vacuum using photo-thermal processing (VPP)[32, $33,34]$.

And as a result, an average transmittance of this film was increased after the treatment. The silicon film was half transparent, brownish colored non-conductive layer with thickness of about $500 \mathrm{~nm}$. This film represents a fully disordered amorphous structure which may be improved using heating. VPP treatment also improves the crystalline structure of such semiconductor thin films [35].

\subsection{Nano-imprinted grating for solar cell efficiency improvement:}

In this the efficiency of a solar cell is enhanced by Nano imprinting rear side gratings which enhances light trapping. The following image shows the Nano-imprinting grating at rear side-

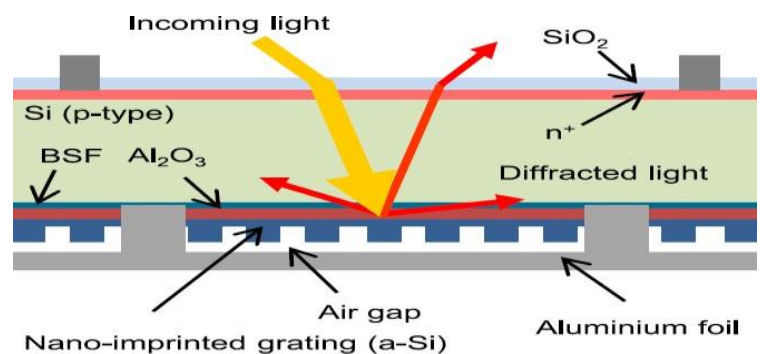

Fig 6 Solar cell with nano-imprinted grating

This enhances the light path inside the solar cell as discussed in the first technique. The increase in the wavelength of light increases the photon absorption capacity of a silicon solar cell which gives an enhancement in increase in the conversion efficiency of a solar cell. The enhancement in the light path for the near infrared reading gives a short circuit current gain of $0.3 \mathrm{~mA} / \mathrm{cm} 2$. But there are still some loses in the rear grating side, whose elimination will lead to the even higher efficiency and higher value gain of short circuit current.

\section{LITERATURE REVIEW}

Mehreen Gul et.al takes special efforts in this paper. This paper mainly studies the inclusive review of solar photovoltaic technology in sense of photovoltaic materials efficiency and globally prime countries. And as result they have found that mono crystalline modules have highest number of efficiency of 22.5\%.[36] T.Thirugnanasambandan et.al has taken a bit more effort to explain the increase efficiency of ultra-thin silicon solar cells with some new methods. Nano composite device were depicted by some electron probe microscope techniques such as SEM, XRD and HR-TEM. [37] Zhang Chunxiao et.al has made this paper mainly focused on the development of current cooling techniques for PV modules and a lot of comparisons, conversations are done for this purpose. Latest reviews have described that with $1^{\circ}$ of increase in cell temperature would decrease efficiency up to 0.4-0.5 \%. [38] Thamyres Mechado David et.alhas taken special efforts in this paper. In this paper, increase in energy demand and how it is going to be supplied world's major issues and challenges is studied. This article shows research possibilities of database about solar PV energy management in terms of bibliometric techniques.[39]

Jia Liu et.al authors in this papers make special focus on photovoltaic-electrical energy storage systems which are moreover utilized in buildings. The EV's (Electrical Vehicle) are given boost in order to storeenergy for PV and increase energy efficiency. The cheaper rate and ecofriendly nature of PV-EV systems have also matched the ever increasing demand large energy storage requirement.[40] $\mathbf{M}$ Fortes et.al and the authors in this paper investigates and describes the efficiency increase of a $\mathrm{Si}: \mathrm{H}$ solar cell by replacing the $\mathrm{n}-\mathrm{i}-\mathrm{p}-\mathrm{p}+$ amorphous silicon solar cell by a textured and reflective one. Finally the author compared the conversion efficiency (Eff) of a solar cell with front and back end textures with experimental set up without front and back end textures and the efficiency was increased from $7.44 \%$ to $11.23 \%$. This states that there is efficiency increased. [41] A K Goyal and the authors in this paper have stated an detailed results of the comparison of the various parameters between CIGS solar cell with ITO and without ITO. Final results have stated that the current generation increases for the solar cell with ITO as afront contact. This is basically because increase in number of charge carriers in solar cell with ITO as compared to the solar cell without ITO. Thus the efficiency of solar cell with ITO has increased. [42]

\section{CONCLUSION}

The effect of replacing amorphous silicon solar cell by a textured and reflective one leads internal reflection of light there is increase in absorption of the photons by the intrinsic layer of solar cell is as it increases the optical length of the device. From simulation study it can be concluded that best efficiency from textured surface with triangular periods (p) of $500 \mathrm{~nm}$ andheight (h) of $75 \mathrm{~nm}$. The conversion efficiency increased from $7.44 \%$ to $11.23 \%$.

And as a result, an average transmittance of this film was increased after the treatment. The silicon film was half transparent, brownish colored non-conductive layer with thickness of about $500 \mathrm{~nm}$. This film represents a fully 


\section{International Journal of Engineering Applied Sciences and Technology, 2021 \\ Vol. 5, Issue 11, ISSN No. 2455-2143, Pages 211-216 \\ Published Online March 2021 in IJEAST (http://www.ijeast.com)}

disordered amorphous structure which may be improved using heating. VPP treatment also improves the crystalline structure of such semiconductor thin films. [43]

\section{REFERENCE}

1. Oisamoje, M.D. and Oisamoje, E.E., 2013. Exploring the economic and environmental benefits of solar energy generation in developing countries: the Nigerian perspective. Journal of Energy Technologies and Policy, 3(6), pp.23-29.

2. Eldin, S. S., Abd-Elhady, M. S., \& Kandil, H. A. (2016). Feasibility of solar tracking systems for PV panels in hot and cold regions. Renewable Energy, 85, 228-233.

3. Choi, J., Lee, H., Jung, B., Woo, J. H., Kim, J. Y., Lee, K. S., ... \& Kim, I. (2018). Co-diffusion of boron and phosphorus for ultra-thin crystalline silicon solar cells. Journal of Physics D: Applied Physics, 51(27), 275101.

4. Moorthy, K., Patwa, N., \& Gupta, Y. (2019). Breaking barriers in deployment of renewable energy. Heliyon, 5(1), e01166.

5. Lewis, N. S., \& Nocera, D. G. (2006). Powering the planet: Chemical challenges in solar energy utilization. Proceedings of the National Academy of Sciences, 103(43), 15729-15735.

6. Diamandis, P. H., \& Kotler, S. (2012). Abundance: The future is better than you think. Simon and Schuster.

7. Herrmann, U., Kelly, B., \& Price, H. (2004). Twotank molten salt storage for parabolic trough solar power plants. Energy, 29(5-6), 883-893.

8. Bagher, A. M., Vahid, M. M. A., \& Mohsen, M. (2015). Types of solar cells and application. American Journal of optics and Photonics, 3(5), 94-113.

9. Coletti, G., Gordon, I., Schubert, M. C., Warta, W., \& Ovrelid, E. J. (2014). Challenges for photovoltaic silicon materials. Solar energy materials and solar cells, 130, 629-633.

10. Yan, B., Yang, J., \& Guha, S. (2012). Amorphous and nanocrystalline silicon thin film photovoltaic technology on flexible substrates. Journal of Vacuum Science \& Technology A: Vacuum, Surfaces, and Films, 30(4), 04D108.

11. Ramos, A., Chatzopoulou, M. A., Guarracino, I., Freeman, J., \& Markides, C. N. (2017). Hybrid photovoltaic-thermal solar systems for combined heating, cooling and power provision in the urban environment. Energy conversion and management, 150, 838-850.

12. Prof. Bharat Raj Singh, Prof. Onkar Singh http://www.solarserver.com/solarmagzine/solar- news/futurescope of solar energy in India, singh raj bharat et.al.

13. Chittaranjan tembhekar ,"indias tops with US in solar power".economic times

14. Shah, A. V., Platz, R., \& Keppner, H. (1995). Thinfilm silicon solar cells: a review and selected trends. Solar energy materials and solar cells, 38(14), 501-520.

15. Guide, Sentaurus Device User, and Device User Guide. "Version M-2017.09." (2017).

16. Lee, S. J., \& Ke, W. C. (2011). Enhanced Diffuse Reflection of Light by Using a Periodically Textured Stainless Steel Substrate. Solar Cells-Thin Film Technologies, 39, 54.

17. Liu, S., Zeng, X., Peng, W., Xiao, H., Yao, W., Xie, X., ... \& Wang, Z. (2011). Improvement of amorphous silicon nip solar cells by incorporating double-layer hydrogenated nanocrystalline silicon structure. Journal of non-crystalline solids, 357(1), 121-125.

18. Beyer, W., Hüpkes, J., \& Stiebig, H. (2007). Transparent conducting oxide films for thin film silicon photovoltaics. Thin solid films, 516(2-4), 147154.

19. A.De Vos, The fill factor of a solar cell from a mathematical point of view, Solar Cells 8 (3) (1983) 283-296.

20. Benanti, T. L., \& Venkataraman, D. (2006). Organic solar cells: An overview focusing on active layer morphology. Photosynthesis research, 87(1), 73-81

21. Voss, B., Knobloch, T., \& Goetzberger, A. (1998). Crystalline silicon solar cells. USA;: Wiley Online Library.

22. Henry, C. H. (1980). Limiting efficiencies of ideal single and multiple energy gap terrestrial solar cells. Journal of applied physics, 51(8), 4494-4500.

23. S.M. Sze, Physics of Semiconductor Devices, John Wiles \& Sons, New York, 1981.

24. Koh, W. S., \& Akimov, Y. (2010). Enhanced light trapping in thin-film solar cells. SPIE Newsroom, 10(2.1201003002654), 1-3.

25. Diukman, I., \& Orenstein, M. (2011). How front side plasmonic nanostructures enhance solar cell efficiency. Solar Energy Materials and Solar Cells, 95(9), 2628-2631.

26. Schaadt, D. M., Feng, B., \& Yu, E. T. (2005). Enhanced semiconductor optical absorption via surface plasmon excitation in metal nanoparticles. Applied Physics Letters, 86(6), 063106.

27. Derkacs, D., Lim, S. H., Matheu, P., Mar, W., \& Yu, E. T. (2006). Improved performance of amorphous silicon solar cells via scattering from surface plasmon 


\section{International Journal of Engineering Applied Sciences and Technology, 2021 \\ Vol. 5, Issue 11, ISSN No. 2455-2143, Pages 211-216 \\ Published Online March 2021 in IJEAST (http://www.ijeast.com)}

polaritons in nearby metallic nanoparticles. Applied Physics Letters, 89(9), 093103.

28. Pillai, S., Catchpole, K. R., Trupke, T., \& Green, M. A. (2007). Surface plasmon enhanced silicon solar cells. Journal of applied physics, 101(9), 093105.

29. Link, S., Burda, C., Wang, Z. L., \& El-Sayed, M. A. (1999). Electron dynamics in gold and gold-silver alloy nanoparticles: The influence of a nonequilibrium electron distribution and the size dependence of the electron-phonon relaxation. The Journal of chemical physics, 111(3), 1255-1264.

30. Axelevitch, A., Gorenstein, B., \& Golan, G. (2012). Investigation of optical transmission in thin metal films. Physics Procedia, 32, 1-13.

31. Axelevitch, A., Gorenstein, B., \& Golan, G. (2014). Application of gold nano-particles for silicon solar cells efficiency increase. Applied surface science, 315, 523-526.

32. Golan, G., Axelevitch, A., Croitoru, N., Inberg, A., \& Gorenstein, B. (2005). In situ evaluation of plane plasma. Plasma Devices and Operations, 13(1), 9-18.

33. Golan, G., Axelevitch, A., \& Rabinovitch, E. (1998). A linear model application for the design of transparent conductive In203 coatings. Microelectronics journal, 29(10), 689-694.

34. Golan, G., Axelevitch, A., \& Rabinovitch, E. (1998). A linear model application for the design of transparent conductive In203 coatings. Microelectronics journal, 29(10), 689-694.

35. Axelevitch, A., Eidin, V., \& Gorenstein, B. (2013). Effect of Photothermal Treatment on Properties of Ge Thin Films. Journal of Materials Science and Engineering. A, 3(7A), 475.

36. Oisamoje, M. D., \& Oisamoje, E. E. (2013). Exploring the economic and environmental benefits of solar energy generation in developing countries: the Nigerian perspective. Journal of Energy Technologies and Policy, 3(6), 23-29.

37. Eldin, S. S., Abd-Elhady, M. S., \& Kandil, H. A. (2016). Feasibility of solar tracking systems for PV panels in hot and cold regions. Renewable Energy, 85, 228-233.

38. Choi, J., Lee, H., Jung, B., Woo, J. H., Kim, J. Y., Lee, K. S., ... \& Kim, I. (2018). Co-diffusion of boron and phosphorus for ultra-thin crystalline silicon solar cells. Journal of Physics D: Applied Physics, 51(27), 275101.

39. Moorthy, K., Patwa, N., \& Gupta, Y. (2019). Breaking barriers in deployment of renewable energy. Heliyon, 5(1), e01166.

40. Liu, J., Chen, X., Cao, S., \& Yang, H. (2019). Overview on hybrid solar photovoltaic-electrical energy storage technologies for power supply to buildings. Energy conversion and management, 187, 103-121.
41. Fortes, M., Belfar, A., \& Garcia-Loureiro, A. J. (2018). Efficiency increase of a-Si: H solar cells with optimized front and back contact textures. Optik, 158, 1131-1138.

42. Kumar, A., Goyal, A. K., Gupta, U., Gupta, N., \& Chaujar, R. (2020). Increased efficiency of $23 \%$ for CIGS solar cell by using ITO as front contact. Materials Today: Proceedings, 28, 361-365.

43. Eisenlohr, J., Tucher, N., Hauser, H., Graf, M., Benick, J., Bläsi, B., ... \& Hermle, M. (2016). Efficiency increase of crystalline silicon solar cells with nanoimprinted rear side gratings for enhanced light trapping. Solar Energy Materials and Solar Cells, 155, 288-293. 